\title{
手延素麵粉末糊のレオロジー特性の厄による変化 一厄により増加する遊離脂肪酸の役割
}

\author{
新原立子*・松本幸雄 ${ }^{* *}$ ・米澤大造***
}

\section{Effect of Yaku on the Rheological Properties of Pastes Prepared from Powdered Somens-Role of Free Fatty Acids Liberated from Lipids in the Somens during Yaku}

\author{
Ritsuko Nrrhara*, Sachio Matsumoto** and Daizo YonezawA*** \\ * Faculty of Education, Kochi University, Akebono-cho, Kochi 780 \\ ** Department of Agricultural Chemistry, College of Agriculture, \\ University of Osaka Prefecture, Sakai-shi, Osaka 591 \\ *** Department of Food Science, Mukogawa Women's University, \\ Ikebiraki-cho, Nishinomiya-shi, Hyogo 663
}

\begin{abstract}
It has long been known that the final step in manufacturing of Tenobe-somen, the so-called $y a k u$, is the necessary storing procedure after the desiccation process of somen so as to provide the most favourable texture when eating the cooked somen. In order to search further insights into the factors affecting the yaku phenomenon, a comparative study on the rheological properties of a series of pastes prepared from the powdered somens before and after the yaku was made within a short span of aging after the paste preparation by means of a cone-plate viscometer at $10^{\circ} \mathrm{C}$. An increase of the steady-flow viscosity and thixotropy followed by a decrease was observed for the pastes prepared from somens before the $y a k u$, while this tendency was much reduced with the samples prepared by use of the powdered somens after the yaku. Such the difference in rheological properties between the two types of the samples is seemingly brought about by the presence of fatty acids liberated in somens during the procedure of yaku. This can be confirmed experimentally using the model system composed of wheat starch, oleic acid, salt and water, so that the fatty acids produced in somens by the yaku procedure may play an important role in the textural properties of cooked somens.
\end{abstract}

(Received Jun. 29, 1984)

手延素麺は，厄を越すこと，すなわち梅雨期の貯蔵を 释ることによってゆで麺のテクスチャーが素麺として好 ましいものに変わるといわれている。今までの研究にお いて，厄処理によるゅで顛のテクスチュロメーター特性 值や麺粉末のアミログラム,フォリノグラムの变化，お よびそれらの要因として素麺に含まれる脂質の貯蔵中の 变化がダルテンやデンプンに与方影響等について報告 した ${ }^{1)}$ 。
ゆでた素麺は冷水で冷やして食膳に供されることが多 い。したがって，ゆで後の時間経過に伴う麺の物性変化 についても考える必要がある。本報では，厄による物性 変化の詳細を知る目的もあって，厄前と厄後の湎粉末で 調製した糊を低温に保ち，糊のレオロジー的性質につい て時間変化を追跡して調べ，厄処理による素麺の遊離脂 肪酸の量的変化との関連について検討した。またこれ とは別に, 脂質変化の影響が素麺中の小麦デンプンに対

\footnotetext{
* 高知大学教育学部 (广 780 高知市曙町 2 丁目 5-1)

**大阪府立大学農学部 (广 591 堺市百舌鳥梅町 4-804)

*** 武庫川女子大学家政学部（广 663 西宮市池開町 6-46）
} 
するものであるか否かについて検討するためにモデル 系を用いて実験を行なったので，それらの結果について 報告する。

\section{試料およひ実験方法}

\section{1. 試料}

素湎：1982 年 2 月に兵庫県龍野市周辺で製面された 手延素奋を室温に 10 月末まで貯蔵したものを厄後の素 缅，湎直後より冷凍庫に保存したものを厄前の素缅と した。なお厄後の素麺も，室温貯蔵後実験に供するまで の間冷冷凍庫に保存した。これらの素湎を粉砝し， 42 × ッシュの節を通した後実験に供した。

その他の試料：小麦デンプンは和光純薬（侏）製の化 学用、オレイン酸は東京化成工業（株）製の純度 $91 \%$ のもの, 䄸実油は半井化学薬品（怢）製の酸価 1 のの を用いた。

\section{2. 素荡の脂質およひ水可溶物質の抽出}

素缅粉末に約 3 倍量のエチルェーテルを加え，筧找後 静置して上登液を G4 のグラスフィルターで沪過した。 この操作を 5 回行ない，沪液を集めて減圧濐縮し，エー テルを除去して脂質を得た。脱脂後の湎粉末に固形物浱 度が $9.36 \%$ となるよう水を加光，室温で 1 時間㨨拌抽 出し, $3800 \mathrm{rpm} て ゙ 10$ 分間遠心分離後の上澄液を No. 131 の沪紙で沪過し，沪液を水可溶物質として用いた。

\section{3. 胡の調製}

素兡粉末 $2 \mathrm{~g}$ 前後をトールビーカーに採取し，固形物 浱度が $9.5 \%$ となるよう水を加え，蓋をして，マグネチ ックスターラーで筧拌しつつ沸滕湯浴中で 20 分間加熱 した。その後 $30^{\circ} \mathrm{C}$ のウォーターバス中で 10 分間冷却 し，蒸発水分量を補充し，㨨捧して均一化した。な⿰扌乇 デル系としての小麦デンプンの場合は，固形物で 7\% 浱 度とし，同様に調製した。

\section{4. みかけの粘度の測定}

円錐平板型粘度計（東京計器株式会社製，EHD 型） 用い，著者ら゙)の方法に準じて以下のごとく行なった。 (1) $10^{\circ} \mathrm{C}$ に保った粘度計内に試料 $1.2 \mathrm{~m} l$ を採取し, 2 分間放置する。(2) ずり速度 $384 \mathrm{~s}^{-1}$ で 3 分間試料を 均一化する。(3) 直ちにずり速度 $76.8 \mathrm{~s}^{-1}$ における試 料のみかけの粘度を 3 分間追跡する。(4) 7 分間静置。 (5) (3)-(4) の操作を 6 回反復する。

\section{結果およひ考察}

\section{1. 素糗粉末糊のレオロジー特性}

上述の，ずり速度 $76.8 \mathrm{~s}^{-1}$ に掞けるみかけの粘度を

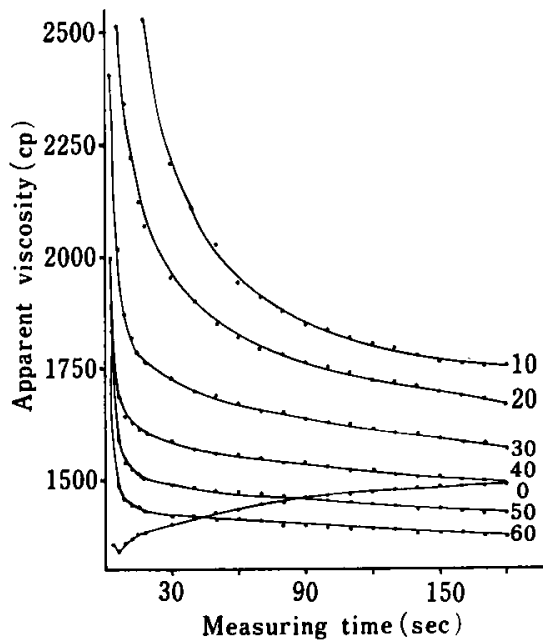

Fig. 1 Changes in apparent viscosity vs. measuring time curve of somen powder paste during aging at $10^{\circ} \mathrm{C}$

Measuring shear rate: $76.8 \mathrm{~s}^{-1}$

Parameters: period of time from the first measurement ( $\mathrm{min}$ )

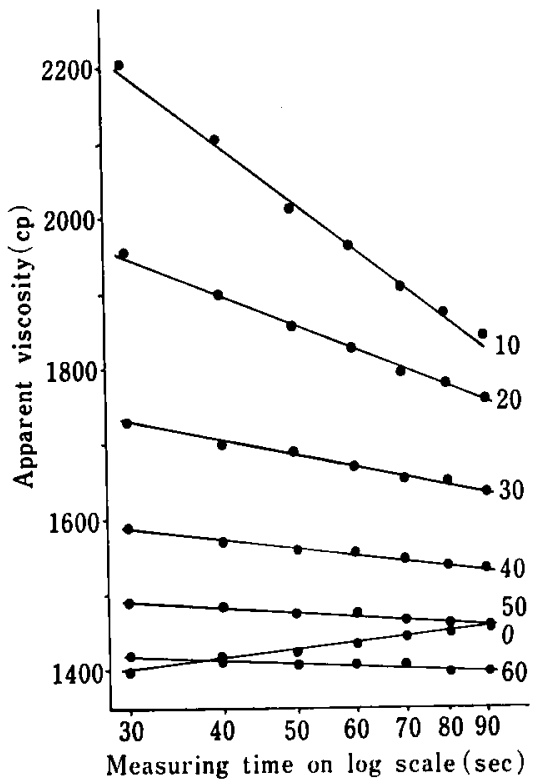

Fig. 2 Correlation between the apparent viscosity and logarithmic measuring time for somen powder paste replotted from the curves in Fig. 1 

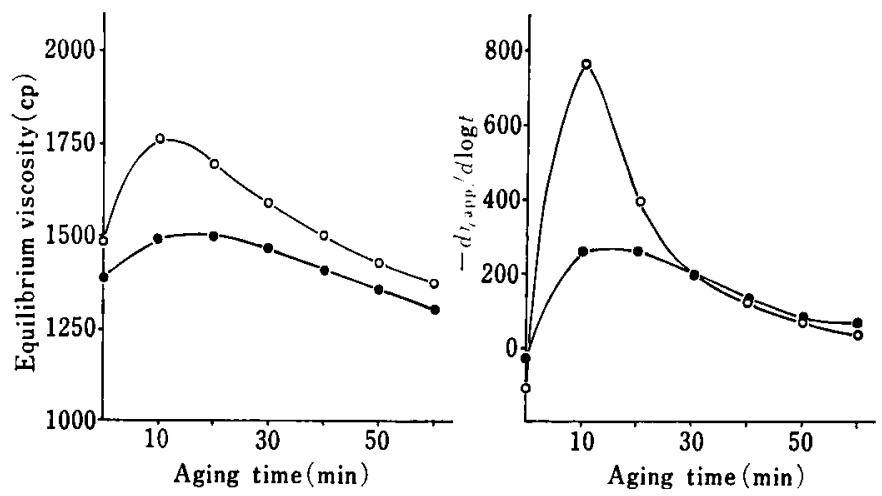

Fig. 3 Changes in equilibrium viscosity and $\left(-d \eta_{\text {app }} / d \log t\right)$ of somen powder paste before and after Yaku during aging at $10^{\circ} \mathrm{C}$ Measuring shear rate: $76.8 \mathrm{~s}^{-1}$ O-O before Yaku

3 分間追跡する操作を反復する実験によって得られた結 果の一例を，厄前の素麺粉末糊について Fig. 1 に示し た。ゼロタイムにおける測定結果, すなわち高いずり速 度で均一化された直後の試料のみかけの粘度は, 測定時 間中にも徐々に増加したが，これは，測定温度 $10^{\circ} \mathrm{C}$ に 保たれている試料に急速なゲル化があらわれるためと思 われる。10 分以後の測定結果では，測定開始とともにみ かけの粘度が减少し, 测定後静置しておくと回復して粘 度が上昇する現象，チキソトロピーが認められた。Fig. 1 について，測定時間の対数を横軸に目盛り，みかけの 粘度との関係をプロットすると，Fig. 2 に示すように 30 秒から 90 秒の間が直線となるので，この直線の傾斜 $\left(d \eta_{\text {app }} / d \log t\right)$ を用いてチキソトロピックな性質の程度 を表わすことができる。また，Fig. 1 によれば，減少 したみかけの粘度は，測定開始後 150 秒でほほ平衡に達 する。したがって，以下に述べる実験結果では，150秒 時のみかけの粘度を平衡粘度とし， $-d \eta_{\mathrm{app}} / d \log t$ をチ キソトロピー性とした。Fig. 3 汇厄前と厄後の麺粉末

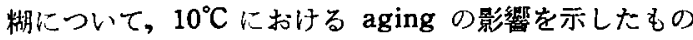
である。困にみられるように，厄前の麺粉末糊の平衡粘 度は放置時間の経過とともに急速に増加し，その後減少 した。粘度增加と平行してチキソトロピーが強くあらわ れ，その後徐々に消失した。厄後の試料は，時間経過に 伴う可衡粘度およびチキソトロピー性の增加制合が厄前 のものに比ベて少なかった。

2. 厄による脂質変化とその影響

Fig. 3 に示した厄前と厄後の湎粉末糊におけるレオ ロジー特性の相違と素湎の脂質变化との関連をしらべる
Table 1 Acid value and peroxide value of lipids extracted from Tenobe-somen

\begin{tabular}{lcc}
\hline Somen & Acid value & $\begin{array}{c}\text { Peroxide value } \\
\text { (meq/kg) }\end{array}$ \\
\hline Before Yaku & 8 & 26 \\
After Yaku & 28 & 25 \\
\hline
\end{tabular}

ために、いくつかの実験を行なった。まず，厄前と厄後 の湎粉末から脂質をエーテルで室温抽出し, 脱脂後の試 料について糊の平衡粘度とチキントロピー性の変化を $10^{\circ} \mathrm{C}$ で測定した。結果は Fig. 4 に示すように，厄前 と厄後の麺粉末糊にみられた差は，麺粉末から大部分の 脂質を除去することによって小さくなり，いずれる無処 理の厄前の特性に近くなった。次に，眖脂後の麺粉末に 抽出した脂質を交換して添加した。すなわち，脱脂した 厄前の麺粉末には厄前の脂質抽出量に相当する量の厄後 の脂質を，厄後の脱脂麺粉末には，同じく厄前の脂質を 添加した。脂質の添加は，エーテルに溶かした脂質を湎 粉末と混合し，室温でエーテルを除去することによっ た。Fig. 5 は，このような方法による厄前と厄後の脂 質交換の影響を示したものである。脂質の交換により， 厄前と厄後の特性が入れ替わることが示された。

次に，厄前と厄後の脂質について過酸化物晌と酸佑を 测定した結果，厄後の脂質は，厄前のものに比べて酸体 が約 3 倍に上昇していたが，過酸化物価には变化が認め られなかった（Table 1)。したがって，厄による脂質変 化は，酸価の上昇にみられる遊離脂肪酸量の增加である 

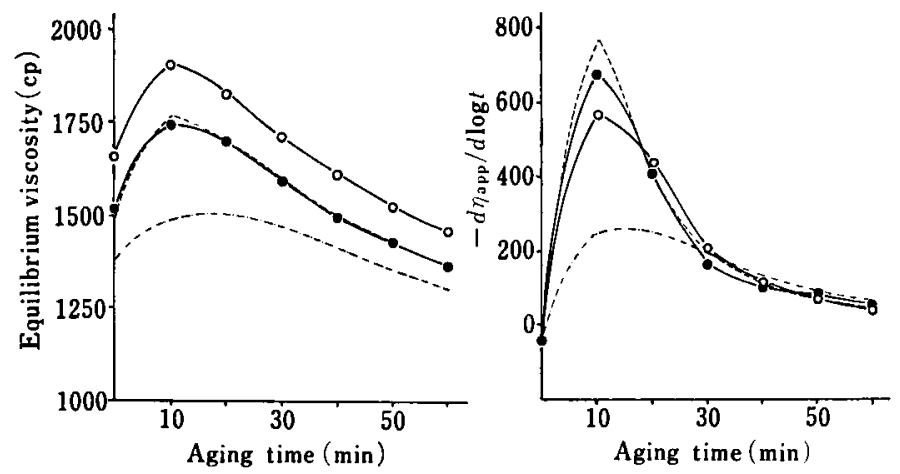

Fig. 4 Effects of defatting on the properties of somen powder paste before and after $Y a k u$

The somen powders were defatted with ethyl ether.

The viscometry was made at a shear rate of $76.8 \mathrm{~s}^{-1}\left(10^{\circ} \mathrm{C}\right)$.

O-O b before Yaku

$$
\text { -— after Yaku }
$$

------- before Yaku without the treatment

-..-. after Yaku without the treatment
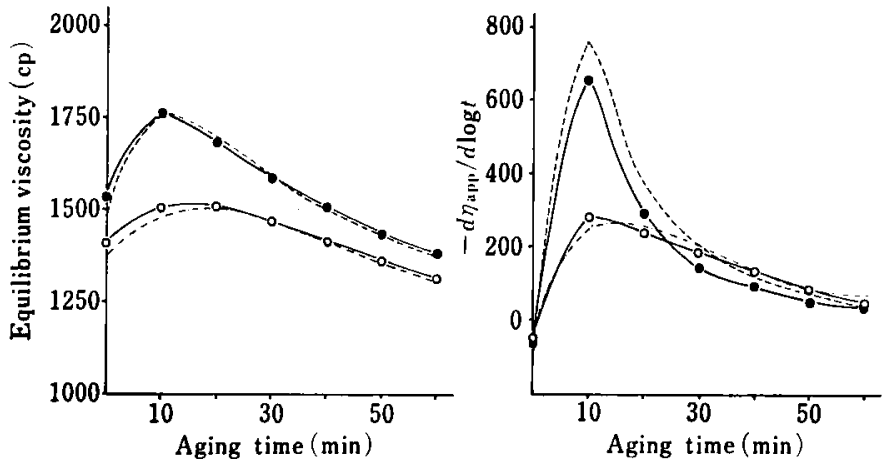

Fig. 5 Effects of interchange of lipids between somen before and after Yaku

The viscometry was made at a shear rate of $76.8 \mathrm{~s}^{-1}\left(10^{\circ} \mathrm{C}\right)$.

O- $O$ before Yaku with lipids after Yaku

- - after Yaku with lipids before Yaku

------ before Yaku without the treatment

-..-. after Yaku without the treatment

と言える。そこで，酸価の上昇分に相当するオレイン酸 を厄前の素兡粉末に添加してその影響をしらべ，その結 果を Fig. 6 に示した。これから明らかなように，オレ イン酸の添加により厄後の試料とほとんど同じ特性があ らわれることがわかる。これらの矢娩結果は，厄後に増 加した肪肪酸が麺粉末糊のレオロジー特性を変化させる ことを示するのである。
3. モデル系としての小麦デンプン糊に対する素糆脂 質の影䇾

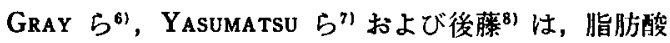
がデンプン糊化時の膨潤を抑制し，フミログラムやプラ ストグラムにおけるデンプン糊の物性に影留を与えるこ とを報告している。一方， $30^{\circ} \mathrm{C}$ に保った小麦デンプン 糊のゲル化時におけるみかけの粘度およびチキントロピ 一性が，脂肪酸との共存により低下することを先に著者 

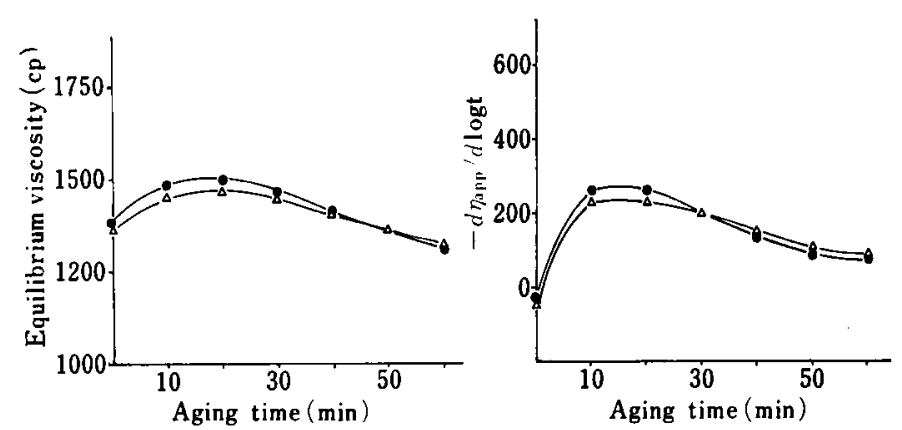

Fig. 6 Effects of addition of oleic acid on the properties of somen powder paste before Yaku

The viscometry was made at a shear rate of $76.8 \mathrm{~s}^{-1}\left(10^{\circ} \mathrm{C}\right)$.

$\Delta-\Delta$ before Yaku with oleic acid

-— after Yaku
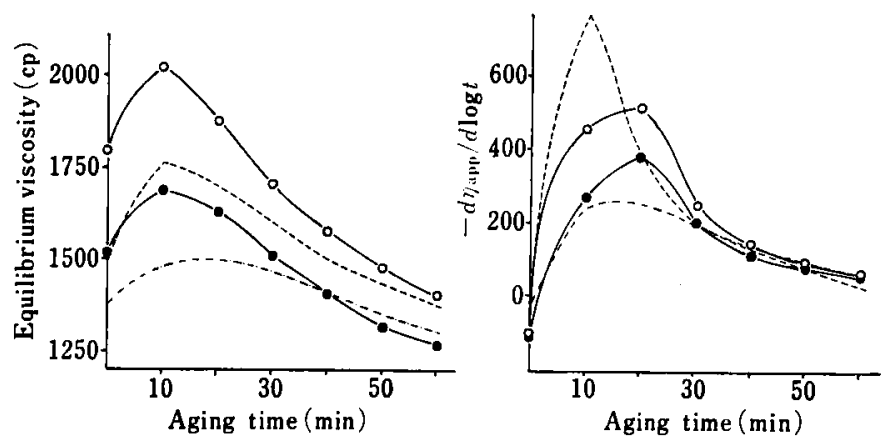

Fig. 7 Effects of somen lipids before and after Yaku on the properties of wheat starch paste containing $\mathrm{NaCl}$

The viscometry was made at a shear rate of $76.8 \mathrm{~s}^{-1}\left(10^{\circ} \mathrm{C}\right)$.

O-O lipids before Yaku

- lipids after Yaku

------ somen powder paste before Yaku

.-.-. somen powder paste after Yaku

ら5) は見出した。これらのことから，前項で述べた素麺 粉末糊に対する脂肪酸の影響は, 素湎の約 $70 \%$ を占め るデンプンに対するむのであろうと考光，次のように設 定されたモデルを用いて実験を行なった。すなわち，小 麦デンプンに厄前と厄後の脂質を乾物量に対し $1.5 \%$ 量 混合し， $0.5 \%$ 食塩水を加えて $7 \%$ 浱度の糊它調製し， 平衡粘度とチキントロピー性の変化を $10^{\circ} \mathrm{C}$ で測定した。 ここで食塩水を用いたのは, 素湎が約 7\%の食塩を含む ためである。その結果は，Fig. 7 に示すように，麺粉 末糊における結果（Fig. 3) を再現しているかけではな いが，厄前と厄後の脂質の相遧による影響が明瞭に認め られた。また，前述した著者らの報告によれば，微量
のオンイン酸をたはバルミチン酸を添加後調製した小麦 デンブン糊は, $30^{\circ} \mathrm{C}$ に aging したときの平衡粘度とチ キントロピー性の增加割合が，無添加のものに比べて小 さく，Fig. 7 と同じ傾向の結果を示した。これらの結 果は, 素湎粉末糊の厄による物性変化が遊離脂肪酸のデ ンプソに対する作用であることを示すむのである。

Fig. 8 は厄前と厄後の素湎の水可溶物犋を素湎の脂質 とともに小麦デンプンに添加し，調製した糊の測定結果 であるが，水可溶物質の添加により試料の示すカーブは 湎粉末糊のカーブに近づき，厄前と厄後の湎粉末糊の相 違が再現された。Fig. 8 の結果にあらわれた 相違の中 には，水可溶物質か厄の前後で变化したことによる影響 


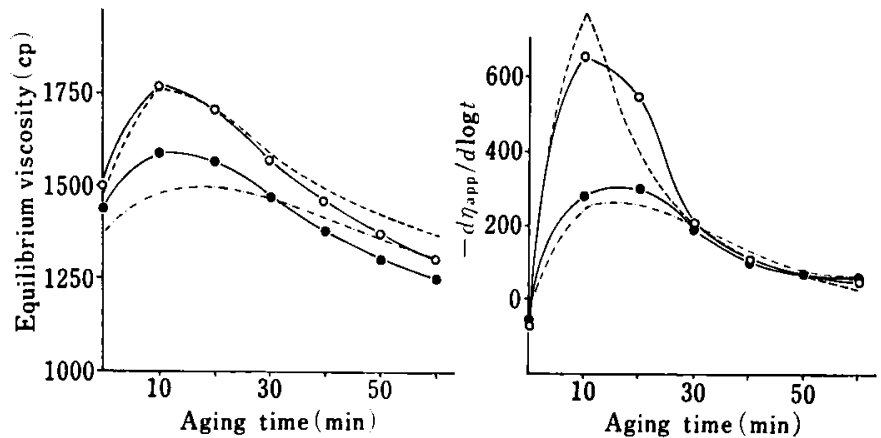

Fig. 8 Effects of lipids and water-extract from somen before and after Yaku on the properties of wheat starch paste

The viscometry was made at a shear rate of $76.8 \mathrm{~s}^{-1}\left(10^{\circ} \mathrm{C}\right)$. $\mathrm{O}-\mathrm{O}$ lipids and water-extract before Yaku

- lipids and water-extract after Yaku

------- somen powder paste before Yaku

-.-. somen powder paste after Yaku

る含まれる可能性が考えられるが，添加する水可溶物質 を厄前のもののみとし，厄前また厄後の脂質と組み合わ せて小麦デンプンに添加した実験でも同梯の結果が得ら れたので，Fig. 8 に示された厄前と厄後の相違は，主 として脂質の相違によってひき起こされたものと判断さ れる。

本実験は，手延素缅の厄によるゆで湎の物性変化に関 して，糊化後の物性についての詳細な情報を得るため と，眝藏中の脂質変化が物性に与える影響を調べるため に行なわれたものである。本実験の結果によれば，厄前 と厄後の物性の相違が最大となるのは $10^{\circ} \mathrm{C} に 10$ 分放置 後であった。したがって，ゆて㒮のテクスチャーも，ゆ で後冷水中にしばらく放置したときに，厄処理による影 響が顕著にあらわれる可能性が考えられる。貯葴中に遊 㜠蓄積した脂肪酸は，タンパク質や食塩の存在下で素湎 をゆでるときのデンプンの膨潤を抑制することを前報》 で報告したが，本実駼の結果から，ゆて逎を放置すると きのテクスチャー変化にも脂肪酸が関与するものと思わ れる。本報のモデル実験の結果は, 脂肪酸の作用は主と してデンプンに対するものであることを示唆しており， そのメカニズムは，パンの老化汇対するもノグリセリド の作用についての ScHocн年 の説と同様に，脂肪酸がフ ミロースと複合体をつくり，デンプン粒の膨潤を抑制し てフミロース分子の溶出を抑える。その結果，厄後の麵 粉末糊はゲルを形成しにくく，時間経過による物性変化 が起こりにくくなるものと推察した。缅粉末に含まれる
水可溶物質は, 脂肪酸の作用を助け, 一方では糊のチキ ソトロピー性に影響を与えるようである。本実験の結果 とゆで麵そのものの調理後のテクスチャー変化との関連 む含めて，今後検討されるべき課題である。

要約

（1）素湎粉末糊を $10^{\circ} \mathrm{C}$ に放置したとき，厄前の試料 の平衡粘度およびチキントロピー性は，時間経過ととも に急速に増加し，その後減少した。厄後の試料は，時間 経過に伴う平衡粘度およびチキントロピー性の増加割合 が厄前のむのに比べて少なかった。

(2) 厄前と厄後の缅粉末糊にみられた特性の相違は， 麺粉末から大部分の脂質を除去すると小さくなり，いず れる無処理の厄前の特性に近くなった。

（3）厄前と厄後の脂質の交換により，それぞれの糊の 特性が入れ替わった。

(4) 厄後の脂質の酸価の上昇分に相当するオレイン酸 を厄前の缅粉末に添加して調製した糊は，厄後の試料と ほとんど同じ特性を示した。

（5）モデル系としての，素缅の脂質を含む小麦デンブ ン糊では，湎粉末糊における結果が再現されたるけでは ないが，厄前と厄後の脂質の相違による影響が明瞭に認 められた。素湎の 水可溶物質を脂質ととむに添加する と,デンプン糊の特性は湎粉末糊の特性に近づき，厄前 と厄後の責粉末糊の相違が再現された。

（6）以上の結果から，厄前と厄後の麺粉末糊のレオロ ジー特性の相違は脂質の変化によるものであって，厄処 
理によって生じた遊離脂肪酸のデンプンに対する作用が 原因であると推論された。

文献

1）新原立子・西田好伸 - 米澤大造・桜井芳人：農化， 47, 423 (1973).

2）新原立子・西田好伸・米澤大造：農化， 47，825 (1973).

3）西田好伸・新原立子・米澤大造：日食工誌，27， 323 (1980).
4) 新原立子 - 米澤大造：日食工誌，28，522(1981).

5) Ninara, R. and Matsumoto, S.: J. Texture Studies, 12, 559 (1981).

6) GraY, V. M. and Sсносн, T. J.: Stärke, 14, 239 (1962).

7) Yasumatsu, K. and Moritaka, S.: J. Food Sci., 29, 198 (1964).

8) 後藤富士雄: 晸粉科学, 19, 76 (1972).

9) Sсносн, Т. J.: Baker's Digest, 39 (2), 48 (1965).

(昭和 59 年 6 月 29 日受理)

\section{新刊紹介}

\section{食品と飲料の分析一最近技術}

\section{George Charalambous 編}

食品の科学と技街モノグラフシリーズのひとつとして 刊行されたもので，従って章を追って体系立てたもので はなく，それぞれの章が尃門家による個別のテーマによ る内容で記述されている。19章の内容のいくつかは次の とおりである。試料調製。官能分析。TLCによる年量。 ガスクロマトグラフィー。高速液体クロマトグラフィー (イオンクロマトグラフィーを含む)。質量分析。核磁気 共鳴。マイコンと無人化。人工香料の活性分析一分子構 造。バイオフッセイ。X線分析。走査形電顕による微細 構造分析。無機元素の原子吸光法。近赤外反射分光分析。 フーリエ变換赤外分光法。溶液化学による自動分析。

645 ページ, 82 ドル

Academic Press Inc., Publishers

Orlando, Florida 32887, U.S. A.

\section{Introduction to Food Engineering}

R. Raul Shingh and Dennis R. Heldman 著

本書は食品科学を尃攻与る学生を対象とした食品工学 の入門書である。

内容は, (1)序編，(2)液状食品の輸送，(3)食品加工の工 ネルギー，(4)食品加工における熱交換，(5)冷蔵, (6)凍結, (7)蒸発，(8)湿度，(9)脱水および補遺である。各編には， 練習問題, 記号のリスト, 参考文献が, 補遺には SI 単 位, 食品と食品以外の物質の物理特性表が記載されてい る。食品工学の入門書として要領よくまとめられてお り，また食品工学に必要な方程式については，各編の中 で例題，計算方法，解答に分け具体的な説明がなされて いる。食品工学を專攻する学生だけでなく, 食品工学の 尃門家ではないがその分野に関心のある方々にとってむ 好著である。

$15 \mathrm{~cm} \times 23 \mathrm{~cm}, 353$ ページ, 35.0 ドル $/ 26.5$ ポンド Academic Press Inc., Publishers

Orlando, Florida 32887, U.S. A. 